\title{
Research Review on Organizational Culture in Private Universities
}

\author{
Mingming Wang \\ Shandong Xiehe University, \\ Jinan 250109, Shandong, China; \\ 476398949@qq.com
}

\begin{abstract}
The main purpose of this study is to systematically sort out the relevant research of organizational culture research in private universities, and to lay a foundation for exploring the path of organizational culture development in private colleges and universities and enhancing the cultural soft power of private colleges and universities. This research uses the literature and comprehensive analysis methods to find out the following conclusions by combing the meaning and structure of the organizational culture of private colleges and universities, the cultural characteristics and problems of private colleges and universities, the types of organizational culture changes, and the path of organizational culture change in colleges and universities. First of all, the existing research has not deepened the overall rational thinking of how to promote the reform of organizational culture in private-owned universities in China, and the lack of research on operability measures and theoretical support are weak. Second, the lack of exploration of organizational culture reform practices in private universities is difficult to sum up an effective path of practice, and it is unable to provide reliable theoretical support for the promotion of cultural soft power. Therefore, systematically designing the path of organizational culture reform in private colleges and universities, the study of reform measures for improving the cultural soft power of private colleges and universities is urgently needed.
\end{abstract}

Keywords: Research review; Private Universities; Organizational Culture

\section{INTRODUCTION}

The adjustment of economic structure and the optimization of industrial structure pose a severe challenge to the development of private colleges and universities with relatively little accumulated foundation and relatively weak foundation (Bie Dongrong, 2014; Xu Xuqing, 2016). In order to promote development, private colleges and universities have reformed and improved both hardware and software, and the teaching facilities and teachers have been continuously improved. Organizational culture, as the spiritual force of the organization's sustainable development, has played an important role in the development of private colleges and universities because of its guiding, restraining, cohesive, and motivating roles. It has received increasing attention and attention ( $R$. Birnbaum, 2003; B.RClark, 2003; Zhang Yingqiang, 2008; Yan Lijun, 2012). Because the unique school-running system, development model, and leadership management mechanism of private colleges and universities have formed its own unique organizational culture that differs from that of public colleges and universities, showing the characteristics of family and enterprise, there are also empty and general values, disorderly institutional culture, and The negative attitudes and behaviors of teachers and students, and the lack of academic ability of material culture, etc., are hampering the sustainable development of private colleges and universities. To sort out the mechanism of organizational culture reform in private universities, to analyze internal and external factors, and to open up and harmonize changes in the organizational culture of private colleges and universities to promote their healthy development has become an important issue.

Studying organizational culture changes is a challenging task for private colleges and universities. Domestic and foreign research on private colleges and universities is relatively weak. However, with universities as research subjects, this issue has undergone some theoretical research and practical exploration. Important reference.

\section{RESEARCH ON THE MEANING OF ORGANIZATION CULTURE AND ITS ELEMENT STRUCTURE IN PRIVATE COLLEGES AND UNIVERSITIES}

The existing research specifically focuses on the lack of organizational culture of private universities. The organizational culture has risen from the 70s and 80 s of the last century and attracted the attention of Chinese and foreign scholars. Scholars at home and abroad have defined the structure of the school's organizational culture and summarized its elemental structure. The definition of Schein (1992) abroad is more popular and widely concerned. He believes that organizational culture is explored, discovered and formed in the process of adaptation to the external environment and internal integration issues. It is divided into basic assumptions and explicit values. And organizations represent three levels. Chen Xiaobin (1999) believes that school organizational culture is the sum of values and behaviors that have been accumulated in long-term activities and that are commonly agreed and followed by all school members. Peng Lan and Zhang Zelin (2004) proposed to solve the problems of internal organization integration and external environment adaptation, identify with symbolic behaviors or activities, form consensus and internalize the shared value of the members of the organization, and then follow them as all members. Ethical norms and behavioral paradigms are enough to affect an internal performance of the school's external effectiveness. Although the definitions of these definitions are not identical, they all include the following meanings: University culture is 
based on universities; subjects are university students, teachers, students, and teaching managers; the core is intangible, decisive concepts and values. It not only maintains the uniqueness of the university, but also maintains the survival and development of the university. Based on the definition of meaning, Lussier and Robert N. (2001) divided the elements of organizational culture into material culture, institutional culture, behavioral culture, and psychological culture. Schein (2014) is divided into artifact level, value level, and implicit hypothesis level. . The domestic scholars mainly include the four-element structure theory: the material layer, the system layer, the spiritual layer, and the behavior layer; the ternary structure theory: the material culture level, the institutional culture level, and the spiritual (values) cultural level (Xu Li, 2010); Structure: Values and Behaviors (Chen Xiaobin, 1999). Therefore, the organizational culture of private colleges and universities is the sum of the values, behaviors, institutional norms, and the material appearance of beliefs and beliefs that have been recognized and followed by the private colleges and universities in the process of long-term running.

\section{RESEARCH ON THE CHARACTERISTICS AND PROBLEMS OF ORGANIZATIONAL CULTURE OF PRIVATE COLLEGES AND UNIVERSITIES}

On the basis of reference and absorption, private universities should give full play to their own characteristics and strengths. This is the same view as the researchers. Researchers have explored the characteristics of the organizational culture of private universities from different perspectives. However, there are problems in the organizational culture of private universities. Need to be clear. China's privately-run higher education is an investment in running schools (Zhai Daguang, 2007). Private colleges and universities have formed their own unique organizational and cultural characteristics, with family-based management, corporate management, corporatization of corporate structures, multi-functional organization functions, and unstable organizational factors. Characteristics of public welfare and utilitarian orientation of organizational values (Zheng Zhiyu, 2005; Zhang Maoshan, 2006). Luo Yin (2013) believes that the organization's value has a dual orientation of public welfare and utilitarian; organizational structure is streamlined, and the pursuit of efficient and pragmatic work style; the relative concentration of internal rights within the organization, the degree of democratization management needs to be improved; the internal organization of the organization has mobility The organizational cohesion needs to be improved; the organizational values are not distinctive, and the organizational personality needs to be demonstrated to be the characteristics of the organizational culture of private universities. Although some scholars have conducted a certain analysis of the characteristics of the organizational culture of private colleges and universities, based on the meaning and elements of the organizational culture of private universities, systematically analyzing the characteristics of their organizational culture and the underlying issues need to be carried out in order to promote private development through planned changes. The positive development of the organizational culture in universities.

\section{A STUDY ON THE TYPES OF ORGANIZATIONAL CULTURE CHANGE IN PRIVATE COLLEGES AND UNIVERSITIES}

The current research on the organizational culture of private colleges and universities, mostly based on the analysis of the status quo and characteristics, points out that the organizational culture of private colleges and universities lacks, proposes countermeasures and suggestions for construction or reform, and analyzes the internal and external factors that affect the organizational culture construction of private colleges and universities. With achievements, on this basis, it is rare to conduct research on organizational cultural changes in private universities. Divided from different perspectives, the reform presents different types, which are divided into intermittent, fragmentary changes and continuous, gradual, incremental changes from the external manifestations (Porras, J., 1991). Greiner (1998) named these two types of organizational reforms as smooth evolutionary and disruptive reforms; divided from internal changes in motivation (Ji Xiaopeng et al., 2011), and first, organizational culture evolution, also known as "non- The organizational culture change of Manz (D. 1990) (Manz, D. 1990) refers to the fact that organizational culture has naturally changed under the condition that organizational managers have not changed the organizational cultural intent. The second is organizational culture reform, also known as "planned" organizational culture change (Manz, D. 1990; Sonn, F., 1993). Organization managers have purposely conducted organizational culture "reforms" so that after reforms Organizational culture can adapt to new requirements. At present, most of the studies on organizational culture change focus on organizational culture management, that is, when the organization is facing major changes (Greiner, L.E., 1998; Leigh, 2007), the organization has planned cultural changes. The reform of organizational culture in private colleges and universities mainly refers to the "planned" organizational culture changes. Therefore, through in-depth investigations, it is necessary to further refine the research on the factors involved in the internal and external environment of private colleges and universities and to explore the relationship between them and organizational culture changes.

\section{V.RESEARCH ON THE PATH OF ORGANIZATIONAL CULTURE REFORM IN PRIVATE COLLEGES AND UNIVERSITIES}

In view of the characteristics of the institutional mechanisms of private colleges and universities, the research on the path of organizational culture reform in private colleges and universities is relatively scarce. Many researchers proposed suggestions and countermeasures for university organizational culture change based on logical deductions or experience-based 
promotion. Wang Jinghua and Yang Xiangrong (2008) believe that the implementation of university organizational culture changes must be based on school discipline and ethos to build the core concept of the university. The banner of the humanistic spirit leads the members in the pursuit of harmony and truth, standardizes school-running behavior, and promotes the school-running level in implementing the school-running philosophy. Peng Lan and Zhang Zelin (2004) believe that the construction of university organizational culture should attach importance to the role of leaders, take the university spirit as the core, use academic ethics as the benchmark, build the humanities university, and create an organizational culture atmosphere. Geng Jiajin (2016) proposes a macro vision, clear organizational mission, consolidates core values, and forms a common belief is an important strategy for organizational cultural development in colleges and universities. Some scholars have also proposed the countermeasures for the organizational culture construction of private universities, starting from the aspects of enriching and perfecting the idea of running schools, standardizing and innovating internal management, promoting and implementing democratic management, and strengthening the internal cohesion of the organization, etc., and proceeding with the development and improvement of organizational culture in private universities (Luo Yin, 2013). ). Based on the integration of theory and demonstration, the research on systematically studying the organizational cultural construction path of localized private universities in China is relatively weak, and it is difficult to guide practice.

In summary, the research on organizational cultural changes domestic and foreign has achieved certain results. However, due to differences in institutional mechanisms, the issue of organizational culture change in private-owned universities in China has its own special laws. Domestic related research is still rare, and it is not common for China's private companies. How to promote the reform of organizational culture in colleges and universities, the overall rational thinking is not deep, operability measures research is inadequate, theoretical support is relatively weak, the path of organizational culture reform of private colleges and universities needs to be unfolded. Second, the lack of exploration of organizational culture reform practices in private universities is difficult to sum up an effective path of practice, and it is unable to provide reliable theoretical support for the promotion of cultural soft power. Therefore, systematically designing the path of organizational culture reform in private colleges and universities, the study of reform measures for improving the cultural soft power of private colleges and universities is urgently needed.

\section{ACKNOWLEDGMENT}

Fund Project: Shandong Xiehe University planning research project: Research on the Construction of Cultural Soft Power in Private Universities (XHXY201714). Supported by scientific research team of Shandong Xiehe University.

\section{REFERENCES}

[1] Bie Dunrong.Reflections on the Transformation and Develop ment of Private Colleges and Universities [J]. University (Ac ademic), 2014,02.

[2] Zhang Yingqiang.University's Cultural Spirit and Mission[M].He Fei:Anhui Education Press,2008.

[3] Peng Lan,Zhang Zeling.On Building of University's Corporate Culture[J].Modern university education,2004,03.

[4] Zhang Maoshan.On the Organizational Culture of Private Col leges and Universities in China[J].Educational Development Research,2006,03.

[5] Geng Jia jin.The Significance and Strategies of Organization CultureConstruction in Colleges and Universities[J].Heilongjiang Researches on Higher Education,2016,06. 